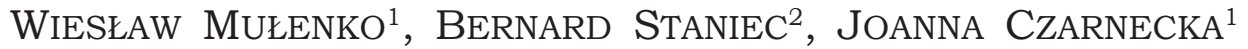 \\ ${ }^{1}$ Katedra Botaniki, Mykologii i Ekologii \\ Instytut Nauk Biologicznych \\ Uniwersytet Marii Curie-Skłodowskiej \\ Akademicka 19, 20-033 Lublin \\ ${ }^{2}$ Katedra Zoologii $i$ Ochrony Przyrody \\ Instytut Nauk Biologicznych \\ Uniwersytet Marii Curie-Skłodowskiej \\ Akademicka 19, 20-033 Lublin \\ E-mail: wieslaw.mulenko@mail.umcs.pl \\ bernard.staniec@mail.umcs.pl \\ joanna.czarnecka@mail.umcs.pl
}

\title{
ZBIORY NAUKOWE WYDZIAEU BIOLOGII I BIOTECHNOLOGII UNIWERSYTETU MARII CURIE-SKŁODOWSKIEJ W LUBLINIE
}

\section{HISTORIA ZBIORÓW PRZYRODNICZYCH - POCZĄTKI KOLEKCJI}

Początki gromadzenia zbiorów naukowych Uniwersytetu Marii Curie-Skłodowskiej w Lublinie sa ściśle zwiazane $z$ jego powołaniem przez Polski Komitet Wyzwolenia Narodowego w dniu 23 października 1944 r. Uniwersytet składał się wówczas z czterech Wydziałów: Lekarskiego, Rolnego, Weterynaryjnego i Przyrodniczego. W 1946 r. Wydział Przyrodniczy przemianowano na Wydział Matematyczno-Przyrodniczy, natomiast w 1952 r. z Wydziału Matematyczno-Przyrodniczego wydzielono Wydział Biologii i Nauk o Ziemi, który funkcjonował do 2011 r., kiedy powołano istniejacy obecnie Wydział Biologii i Biotechnologii.

Od początku funkcjonowania Uniwersytetu i Wydziału kompletowano nie tylko aparaturę naukowa i ksiegozbiory, ale także gromadzono okazy różnych grup systematycznych roślin, grzybów, zwierzat i skamielin. Były one wykorzystywane zarówno do celów naukowych, jak i dydaktycznych. Eksponowano je także na doraźnych wystawach okolicznościowych i w Muzeum Zoologicznym, pierwszym i jedynym w Lublinie, powstałym w 1946 r., którego pierwszym kustoszem był dr Zdzisław Raabe. Obecnie wszystkie zbiory naukowe Wydziału sa pod opieka pracowników Katedry Botaniki, Mykologii i Ekologii, Katedry Zoologii i Ochrony Przyrody oraz Pracowni Edukacji Biologicznej i Środowiskowej z Muzeum Zoologicznym.

Uniwersytet Marii Curie-Skłodowskiej jest względnie młoda instytucja, dlatego większość kolekcji pochodzi $z$ okresu drugiej połowy XX w. Zbiory zielnikowe UMCS sa rezultatem ponad 70-letnich badań florystycznych, geobotanicznych, fitosocjologicznych, ekologicznych, mykologicznych, mykosocjologicznych i taksonomicznych. Założycielem zielnika lubelskiego był prof. Józef Motyka (1900-1984), wybitny polski lichenolog, botanik i ekolog, który w latach 1944-1970 kierował Katedra Systematyki i Geografii Roślin. Profesor wyszedł $z$ założenia, że osoby pracujace naukowo w danej jednostce powinny w niej gromadzić swoje zbiory naukowe. Dlatego wszystkie zebrane okazy porostów i roślin były opatrywane drukowanymi etykietami Katedry Systematyki i Geografii Roślin. Najbardziej cenne sa kolekcje najstarsze, historyczne, gromadzone jeszcze przed powołaniem Uczelni, a następnie tu zdeponowane. Najstarsze posiadane okazy roślin sa datowane na druga połowę XIX

Słowa kluczowe: bioróżnorodność, Uniwersytet Marii Curie-Skłodowskiej, zbiory przyrodnicze, kolekcja botaniczno-mykologiczna, kolekcja entomologiczna

*Artykuł powstał dzięki wsparciu finansowemu z projektu POPC.02.03.01-00-0081/19 "Integracja i mobilizacja danych o różnorodności biotycznej Eukaryota w zasobach polskich instytucji naukowych" (IMBIO). 
w., np.: 1869 r. (K. Łapczyński), 1884 r. (F. Gárard), czy okazy zebrane przez F. Berdaua (1826-1895), chociaż niektóre $z$ nich nie posiadaja dat zbioru. Dotychczas nie ustalono, $\mathrm{w}$ jaki sposób pewne alegaty zielnikowe dotarky do zielnika lubelskiego.

Wśród okazów $\mathrm{z}$ początków $\mathrm{XX}$ w., zwłaszcza $z$ okresu międzywojennego, dominuja zbiory lichenologiczne prof. Motyki, który po ukończeniu studiów na Uniwersytecie Jagiellońskim pracował jako adiunkt w Ogrodzie Botanicznym Uniwersytetu Jana Kazimierza we Lwowie. Tam też rozpoczał studia nad porostami, które stały się głównym przedmiotem jego zainteresowań, a po II wojnie światowej odzyskał większość własnych przedwojennych zbiorów.

Znaczna część najstarszych kolekcji botanicznych stanowia okazy roślin kwiatowych. Niektóre $z$ nich zostały zebrane przez botaników niemieckich podczas I i II wojny światowej. Do zbiorów roślin naczyniowych właczono również stosunkowo dużą kolekcję Haliny Koporskiej, pochodzaca $z$ okresu międzywojennego, która została ofiarowana przez Biblioteke im. Hieronima Łopacińskiego w Lublinie. Cecha charakterystyczna niektórych okazów okresu międzywojennego sa pięknie wykaligrafowane etykiety danych (np. J. Urbańskiego, H. Koporskiej). W 1947 r. opieka nad zbiorami roślin naczyniowych została powierzona prof. Dominikowi Fijałkowskiemu (1922-2015), wówczas jeszcze studentowi. Już pod koniec pierwszego roku jego pracy zielnik powiększył się o kilka tysięcy arkuszy roślin $z$ różnych grup taksonomicznych i ekologicznych.

Poczatki kolekcji mchów i watrobowców sa zwiazane $z$ prof. $\mathrm{dr}$ hab. Kazimierzem Karczmarzem (1933-2011), który w 1956 r. został zatrudniony na etacie asystenta w Katedrze Systematyki i Geografii Roślin. Odbył staże naukowe w uznanych ośrodkach w Leningradzie, Kijowie, Helsinkach, Wiedniu i Jenie. Uczestniczył także $\mathrm{w}$ wielu międzynarodowych ekspedycjach naukowych do Azji Środkowej, Indii, Nepalu i na Półwysep Kola. Zgromadzone podczas wyjazdów zbiory pozwoliły na opracowanie flory mszaków Mongolii, Azji Środkowej i Spitsbergenu.

Zbiory mykologiczne zostały zapoczatkowane w latach 70. XX w. przez prof. dr hab. Bogusława Sałate (1940-1999), który ukończył studia w 1963 r., przygotowujac prace magisterską $\mathrm{w}$ zakresie geobotaniki pod kierunkiem prof. Józefa Motyki, a następnie, pod jego wpływem, rozpoczą badania mykologiczne. Poczatkowo dotyczyły one grzybów wielkoowocnikowych i ich udziału w zbiorowiskach leśnych Roztoczańskiego PN. Prace te zapoczątkowały intensywny rozwój mykologii w ośrodku lubelskim oraz zainicjowały powstanie zielnika mykologicznego.

W 2006 r. nastapiło scalenie wszystkich istniejacych dotychczas kolekcji zielnikowych Wydziału Biologii i Biotechnologii UMCS w jeden, największy, jedyny we wschodniej Polsce, zbiór materiałów zielnikowych. Jest on znany na całym świecie. Informacje o nim znajduja się m.in. w opracowaniu MIRKA (1997) i KÖHLERA (2007), a w światowej bazie danych "Index Herbariorum" zielnik lubelski oznaczony jest akronimem LBL.

Zbiory entomologiczne w kolekcjach Wydziału Biologii i Biotechnologii UMCS byly gromadzone systematycznie przez niemal 140 lat i pochodza $z$ różnych rejonów kraju i świata. Dominuja okazy ze wschodniej Polski, obszaru, który pod względem różnorodności i bogactwa fauny należy do jednych $z$ najciekawszych w Europie. Obszar ten obfituje w gatunki o zróżnicowanych wymaganiach ekologicznych, reprezentujace rozmaite elementy zoogeograficzne. Najstarsze okazy owadów, a jest ich kilkaset, pochodza $z$ końca lat 70. i 90. XIX w. oraz z poczatków XX w. Na uwage zasługuje Tropidothorax leucopterus Goeze, pluskwiak (Hemiptera), odłowiony 5.10.1879 r. w krakowskich Przegorzałach, który jest najstarszym okazem kolekcji. Owady $z$ tego okresu były zbierane głównie przez Stanisława Smreczyńskiego (seniora), zasłużonego polskiego entomologa, pedagoga, nauczyciela przyrody oraz historii naturalnej w szkołach średnich Krakowa i Tarnowa, absolwenta Uniwersytetu Jagiellońskiego, członka Komisji Fizjograficznej Polskiej Akademii Umiejętności, który badał prostoskrzydłe (Orthoptera) i pluskwiaki (Hemiptera) na przełomie XIX i XX w. Opisał 27 gatunków pluskwiaków różnoskrzydłych (Heteroptera) i 57 gatunków piewików (Auchenorrhyncha) $z$ terenów ówczesnej Galicji. Znacznie więcej, bo ponad 1000 okazów (w przewadze chrzaszcze), zgromadzono w latach 1910-1950. Pochodza one z Polski, Niemiec i innych krajów europejskich (zbiory Kuntzego, Polentza, Jordana, Eigena, Josifova, Wagnera, Kulikowa, Rysakova, Kiritshenki, Triapicyna i Martino).

\section{LOKALIZACJA I OBECNY STAN ZBIOROW}

Zbiory naukowe UMCS przez długi czas były gromadzone $\mathrm{w}$ pomieszczeniach pracowniczych, na korytarzach lub $\mathrm{w}$ wielu innych miejscach narażonych na działanie zagrażających czynników szkodliwych (np.: wilgoć, gryzonie, owady). Sytuacja uległa zmianie dopiero w 2006 r., kiedy Fundacja na rzecz Nauki Polskiej (FNP), w ramach programu BIOS, wsparła finansowo modernizację wa- 

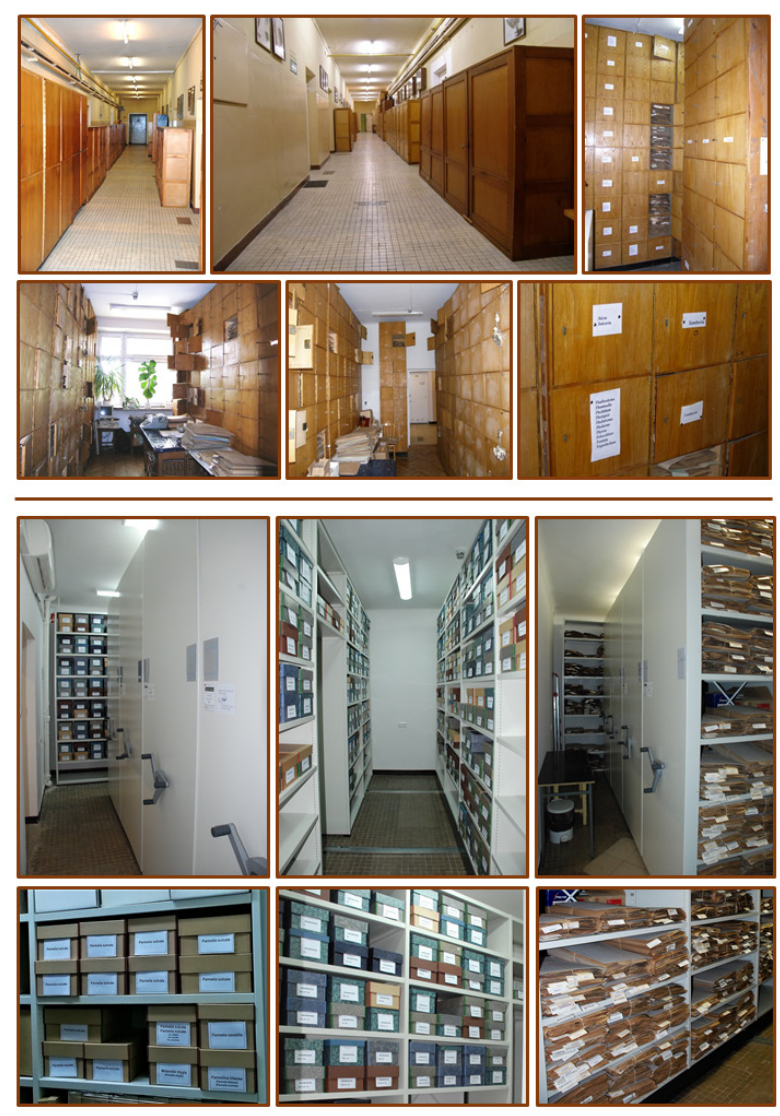

Ryc. 1. Zielnik Katedry Botaniki, Mykologii i Ekologii (LBL): część górna - przed modernizacją; część dolna - po modernizacji, $z$ funduszy dotacji Fundacji na rzecz Nauki Polskiej (fot. W. Mułenko).

runków przechowywania zbiorów. Dzięki temu zaadaptowano specjalne pomieszczenia na kolekcję zielnikowa, wyposażając je w szafy jezdne i regały stacjonarne. Dodatkowo, od 2011 r., po połaczeniu zbiorów zoologicznych i zielnikowych w jeden zbiór Wydziału Biologii i Biotechnologii, uzyskano kilkakrotnie ministerialna dotację w ramach SPUB-u. Dzięki temu obecnie kolekcje botaniczne i mykologiczne znajduja się w specjalistycznych pomieszczeniach (Ryc. 1).

Główna część zbiorów owadów zdeponowana jest w specjalnie wyposażonym pokoju zbiorów w Katedrze Zoologii i Ochrony Przyrody UMCS. Natomiast pozostała ich część, obejmujaca motyle większe (Macrolepidoptera), znajduje się w zbiorach Muzeum Zoologicznego. Również dzięki wspomnianemu wsparciu finansowemu SPUB, pomieszczenia do przechowywania zbiorów zostały wyposażone w specjalistyczne regały, witryny, pudła, gabloty, szafy katalogowe i segregatory. Ponadto, zaadaptowano niektóre pomieszczenia w zakresie utrzymania odpowiednich warunków mikroklimatycznych i zorganizowano specjalistyczne pomieszczenie do odkażania zbiorów.

\section{KOLEKCJA BOTANICZNO- MYKOLOGICZNA}

Stan liczbowy obecnej kolekcji botaniczno-mykologicznej Wydziału BiB UMCS nie został jeszcze dokładnie określony. Również nie dokumentowano zakresu udostępniania okazów innym instytucjom. Wobec tego obecnie otrzymujemy regularnie zwroty kompletów okazów $z$ różnych instytucji polskich i zagranicznych, w zwiazku z czym obecne dane maja charakter szacunkowy.

\section{ZIELNIK BOTANICZNY}

Zielnik botaniczny obejmuje rośliny naczyniowe, glony, mchy i wątrobowce, które pochodza $z$ różnych rejonów geograficznych Lubelszczyzny: Wyżyny Lubelskiej, Wyżyny Zachodniowołyńskiej, Polesia, Roztocza i Lasów Janowskich, w tym $z$ tutejszych parków narodowych, a także z Bieszczad, Beskidów i Pojezierza Mazurskiego. Na szczególna uwagę zasługuja kolekcje flory dolin rzecznych Wisły, Bugu i Sanu oraz dróg i linii kolejowych, zebrane w trakcie badań poswięconych roli rzek jako naturalnych korytarzy ekologicznych, a dróg i linii kolejowych - jako korytarzy sztucznych, sprzyjających rozprzestrzenianiu się gatunków inwazyjnych (Ryc. 2).

Obfite zbiory mchów i wątrobowców zgromadzono również podczas badań prowadzonych w wielu krajach europejskich i w Azji. Zielnik zawiera m.in. 3 nowe dla nauki gatunki $z$ rodzaju Calliergon oraz ponad 20 taksonów innej rangi opisanych przez prof. K. Karczmarza. W tym zbiorze znajduja się także liczne próby glebowe, utwory skalne i skamieliny. Bardzo obfite i cenne materiały pochodza również z 6 międzynarodowych wypraw naukowych na Spitsbergen, do Mongolii i Wschodniej Ukrainy oraz ze wspólnych badań prowadzonych we współpracy $z$ ośrodkami naukowymi na Litwie, Ukrainie i Białorusi. Ponadto, w zielni$\mathrm{ku}$ znajduja sie zbiory pochodzace $\mathrm{z}$ Włoch, Francji, Grecji i Węgier. Wyjątkowo cenna jest kolekcja mchów i wątrobowców Antona J. Grawa, badacza flory mszaków Śląska. Powstała w latach 30. i 40. XX w., ale nie wiadomo w jaki sposób znalazła się w Lublinie. Niewielkie jej części znajdują się również w Muzeum Śląska Opolskiego w Opolu oraz w zielnikach Berlina i Monachium. Herbarium lubelskie obejmuje 95\% polskiej części omawianej kolekcji. Zbiór LBL liczy ponad 350 alegatów mszaków, w tym 2 gatunki glewików, 37 gatunków wątrobowców 



Ryc. 2. Starsze i ciekawsze okazy wybranych gatunków roślin w herbarium LBL: A - Potamogeton natans (okolice Ludwikowa, 1926 r.), B - Rubus nemorosus (okolice Kielc, 1927 r.), oba $\mathrm{z}$ Zielnika Jarosława Urbańskiego; C - Quercus robur (Kazimierz n. Wisła, 1932 r.), z Zielnika Bożenny Papiewskiej; D - Picea nigra (Puławy, zbiór F. Berdaua, II połowa XIX w., szczegółowej daty brak); E - Cypripedium calceolus (okolice Wilna, leg. S. Trzebiński, 1927); F - Juniperus communis (Tuchowicz, pow. łukowski, leg. K. Łapczyński, 1869); G - Allium victorialis (Roztocze, leg. K. Izdebski, 1958); H - Gladiolus paluster (Dolny Śląsk, leg. W. Berdowski, 1963); I - Allium schoenoprasum (Lublin, leg. D. Fijałkowski, 1949) (fot. W. Mułenko).

oraz 100 gatunków mchów $z$ obecnego terytorium Polski, a także 6 gatunków mchów pochodzacych $z$ Austrii i 3 gatunki z Czech. Za unikatowy uznajemy także ogromny zbiór mszaków zgromadzonych na stałych powierzchniach badawczych Roztoczańskiego Parku Narodowego.

\section{ZIELNIK MYKOLOGICZNY}

Zielnik mykologiczny zawiera wszystkie grupy taksonomiczne grzybów, włącznie $z$ porostami, które pochodza głównie $z$ obszarów chronionych makroregionu lubelskiego, parków narodowych: Poleskiego i Roztoczań-
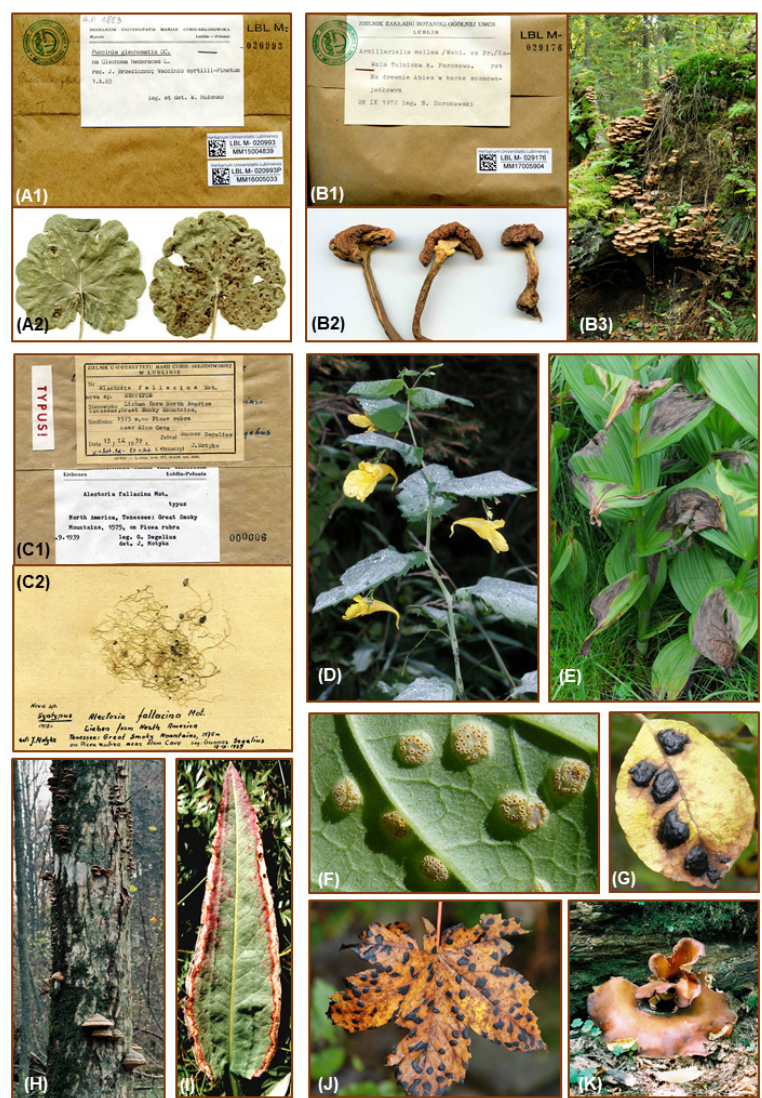

Ryc. 3. Wybrane gatunki ze zbiorów mykologiczno-botanicznych oraz $z$ dokumentacji fotograficznej in situ: A1 i A2 - rdza Puccinia glechomatis na Glechoma hederacea (koperta oraz porażona przez grzyb roślina - przykład podwójnego rekordu w bazie); B1, B2, B3 - opieńka Armillaria mellea s. lat. (koperta, zasuszony okaz oraz w naturze - na kłodzie drzewa w Puszczy Białowieskiej); $\mathrm{C} 1, \mathrm{C} 2$ - porost Alectoria fallacina - typ nomenklatoryczny, okaz na podstawie którego opisano nowy dla nauki gatunek porostu (koperta i okaz); D - maczniak prawdziwy Sphaeroteca balsaminae na Impatiens noli-tangere (Tatry, Słowacja, 2010); E - szara pleśń Botrytis cinerea na liściach Veratrum lobelianum (Tatry, Słowacja); F - ecja rdzy Puccinia poarum na liściach Petasites albus (Tatry, Polska); G - łuszczeniec wierzbowy Rhytisma salicinum na Salix sp. (Tatry, Słowacja); H - różne gatunki grzybów, mchów i porostów na pniu graba Carpinus betulus (Puszcza Białowieska); I grzyb głowniowy Ustilago marginalis na Polygonum bistorta (Tatry, Słowacja); J - łuszczeniec klonowy Rhytisma salicinum na Acer pseudoplatanus (Tatry, Polska); K - żagiew kasztanowa Polyporus badius na kłodzie drzewa (Puszcza Białowieska) (fot. W. Mułenko).

skiego, parków krajobrazowych: Lasy Janowskie, Kazimierski PK, a także $z$ Białowieskiego i Tatrzańskiego Parku Narodowego. Poza wymienionymi obszarami, okazy porostów 
pochodzą także z: Ukrainy, Szwecji, Norwegii, Finlandii oraz $z$ wielu innych krajów europejskich, jak również $z$ obu Ameryk (np. zbiory prof. J. Motyki) (Ryc. 2). W całej kolekcji porostów znajduje się ponad 200 typów nomenklatorycznych. Pochodza niemal ze wszystkich kontynentów, spośród których największą liczbę nowych dla nauki gatunków opisał J. Motyka. Kilkadziesiąt taksonów różnej rangi (w tym gatunków) opisał również prof. Jan Bystrek. W zielniku znajdują się też kolekcje grzybów pasożytniczych zebranych podczas badań prowadzonych w Wielkiej Brytanii, Korei Południowej, Czechach oraz na Ukrainie i Słowacji lub dublety pochodzace $z$ wymiany $z$ innymi ośrodkami polskimi i zagranicznymi (np. USA, Niemcy). Spośród grzybów pasożytniczych roślin, zebranych w Puszczy Białowieskiej, w Tatrach i w Lublinie prof. Wiesław Mułenko ze współpracownikami opisał 5 nowych dla nauki gatunków (Ryc. 3).

Zgromadzony materiał zielnikowy jest reprezentatywny dla całego południowo-wschodniego regionu Polski, a niektóre jego działy, np. lichenologiczny, sa podstawową baza do rewizji taksonomicznych. Duża część zbiorów mykologicznych stanowi dokładna, niepowtarzalna dokumentacja pochodzaca $z$ wieloletnich obserwacji na stałych powierzchniach lub $z$ wieloletnich badań wielkoobszarowych $\mathrm{w}$ trudno dostępnym terenie. Obserwacje mykologiczne (zwłaszcza $\mathrm{w}$ zakresie mykocenologii), ale też badania innych organizmów zarodnikowych w strukturze zbiorowisk naturalnych, należą do unikatowych. Sa to m.in. zbiory grzybów pasożytniczych roślin pochodzace $z$ Białowieskiego Parku Narodowego oraz $z$ lasów reglowych Tatr słowackich. Bogaty jest również zbiór roślin zgromadzonych podczas prawie 20-letnich badań prowadzonych na obszarze całych Tatr oraz zbiór materiałów $z$ badań w lasach kaledońskich Szkocji, jak również kolekcja grzybów inwazyjnych w Polsce, które zostały zebrane przez mykologów lubelskich w latach 2004-2007.

\section{IKONOTEKA}

Mająca wartość muzealna ikonoteka roślin wyższych, licząca ok. 400 tablic malowanych akwarela, została przywieziona po II Wojnie Światowej $z$ Uniwersytetu im. S. Batorego w Wilnie przez prof. Piotra Wiśniewskiego, pierwszego kierownika i założyciela ówczesnego Zakładu Botaniki Ogólnej. Autorem grafik jest Konstanty Prószyński, botanik i mykolog, inspektor Ogrodu Botanicznego Uniwersytetu Wileńskiego. Obecnie zbiór jest właściwie zabezpieczony przed zniszczeniem i znajduje się w zielniku Katedry Botaniki, Mykologii i Ekologii.

\section{BOGACTWO I RÓŻNORODNOŚĆ ZBIORÓW}

Liczba arkuszy zielnikowych (kopert) zbiorów przyrodniczych UMCS jest oceniana na ok. 400000 . Szacuje się, że zbiory botaniczne obejmuja ok. $50-60 \%$ bogactwa gatunkowego roślin wyższych, porostów i mszaków, wykazywanych dotychczas $z$ calego obszaru Polski. Natomiast nasze zbiory mykologiczne należą do jednych $z$ większych w kraju.

\section{ZASOBY ZIELNIKOWE}

(liczba eksykatów, kopert zielnikowych, egzemplarzy)

\begin{tabular}{llr} 
flora & & \\
rośliny naczyniowe & - ok. & 175000 \\
mchy & - ok. & 30000 \\
watrobowce + glewiki & - ok. & 6000 \\
glony & - ok. & 2000 \\
łacznie & - ok. & 213000 \\
\hline
\end{tabular}

\begin{tabular}{|c|c|}
\hline & $\begin{array}{c}\text { - ok. } \\
\text { grzyby mikroskopiin }\end{array}$ \\
\hline (mikromycetes) & $\begin{array}{rr}- \text { ok. } & 25000 \\
\text { grzyby makroskopowe }\end{array}$ \\
\hline (makromycetes) & - ok. \\
\hline porost & - ok. \\
\hline acznie & - ok. \\
\hline
\end{tabular}

Sumaryczna liczba posiadanych okazów - ok. 390000

\section{KOLEKCJA ENTOMOLOGICZNA}

Zbiory entomologiczne obejmuja ponad 20000000 okazów, reprezentujących ponad 5400 gatunków. Sa przechowywane „na sucho”, w formie trwałych preparatów mikroskopowych lub sa zakonserwowane w alkoholu. Znaczna ich część, szczególnie muchówki i niektóre okazy reprezentujace inne taksony, wymaga jeszcze szczegółowego opracowania. Przedstawiaja bardzo duża wartość naukowa, zarówno w skali Polski, jak i Europy. Świadczy o tym choćby obecność 21 okazów typów opisowych, w tym 11 holotypów i 10 paratypów, będacych okazami wzorcowymi opisu nowych dla nauki gatunków. Unikatową wartość przedstawia także zbiór larw i poczwarek wyhodowanych lub zebranych, $z$ których część wciąz czeka na opracowanie. Poza tym w zbiorach znajduje się kilkanaście gatunków, których okazy dowodowe w skali Polski znajduja się wyłacznie w opisywanej kolekcji. Warto też nadmienić, że pod względem liczby okazów i gatunków krajowych, które reprezentuja: Hemiptera, Curculionoidea, Staphylinidae, Thysanoptera, Odonata i Chloropidae, nasze 

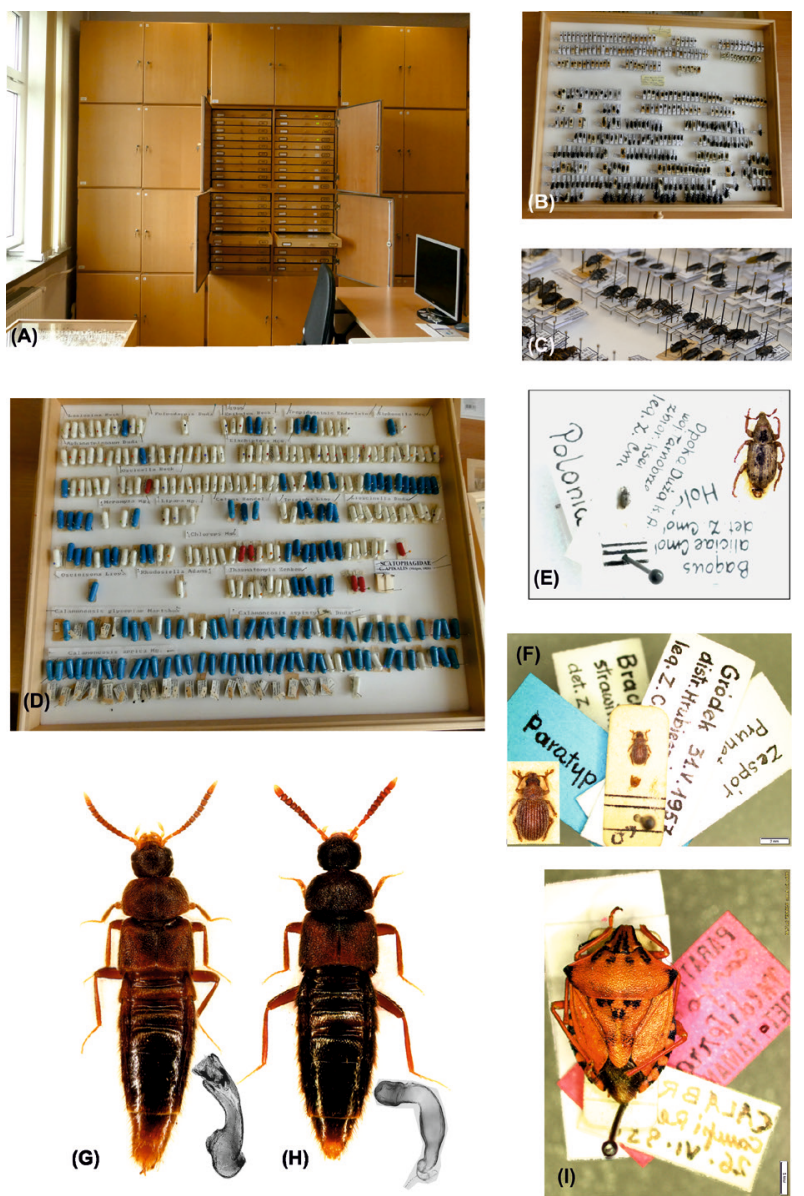

Ryc. 4. Zbiory entomologiczne przechowywane „na sucho": A - szafy $z$ gablotami entomologicznymi; B i C - gablota $z$ chrzassczami; D - gablota $z$ muchówkami zabezpieczonymi w plastikowych kapsułkach; E - okaz holotypowy ryjkowca Bagous aliciae Cmoluch; F - okaz paratypowy Brachysomus strawińskii Cmoluch; G - okaz holotypowy kusaka (samiec $z$ wyizolowanym aedeagusem) Thiasophila szujeckii Zagaja \& Staniec; H - okaz paratypowy (samica $Z$ wyizolowana spermateka) Thiasophila szujeckii Zagaja \& Staniec; I - okaz paratypowy pluskwiaka Carpocoris mediterraneus Tamanini (fot. B. Staniec).

zbiory należą do najbogatszych $\mathrm{w}$ Polsce, a $\mathrm{w}$ przypadku myrmekoflnych chrząszczy oraz larw Staphylinidae, Curculionidea i Thysanoptera do jedynych w kraju i nielicznych na świecie.

\section{ZBIORY PRZECHOWYWANE „NA SUCHO”}

Najlepiej uporządkowany, opisany i zawierajacy okazy oznaczone w znacznej większości do rangi gatunku (rzadziej rodzaju), jest zbiór owadów spreparowanych i przechowywanych „na sucho" w szczelnie zamkniętych gablotach ze szklanymi szybami w stojacych szafach (Ryc. 4A-C). Jego nie- wielka cześć, obejmujaca głównie chrzaszcze $z$ nadrodziny Curculionoidea i muchówki, jest przechowywana w plastikowych kapsułkach (Ryc. 4D).

Unikatowa wartość ma zbiór ok. 1000 chrząszczy i pluskwiaków (różne rodziny), pochodzacych $z$ włoskiej wyspy Asinary, które zostały zgromadzone przez A. Oczkowskiego w maju i czerwcu 1918 r. Niestety, większość $z$ nich, $z$ wyjątkiem ryjkowców, nie doczekała się jeszcze identyfikacji, a cześć okazów nie posiada etykiet zbioru.

W kolekcji jest ponadto ok. 1000 okazów chrząszczy i ponad 5000 okazów pluskwiaków odłowionych w drugiej połowie minionego stulecia w Bułgarii, Rumunii, południowej i zachodniej części obecnej Ukrainy, a także w dawnych republikach radzieckich, głównie w Kazachstanie, Azerbejdżanie, Tadżykistanie, Turkmenistanie, Uzbekistanie, Gruzji, jak również w Iranie.

Większość okazów pochodzi $z$ drugiej polowy XX i z XXI w. Zostały zebrane w różnych regionach Polski, większość $z$ nich $\mathrm{w}$ jej części wschodniej (Wyżyna Lubelska, Roztocze, Polesie Lubelskie, Podlasie, Nizina Sandomierska, Bieszczady). Wśród nich jest wiele gatunków rzadko spotykanych $\mathrm{w}$ skali kraju lub Europy, ginących lub zagrożonych wyginięciem, które na wschodzie Polski maja swoje kresy zasięgu. $Z$ tego obszaru jest też szereg okazów typowych (holotypy i paratypy) reprezentujących 10 gatunków opisanych po raz pierwszy dla nauki.

Zbiory entomologiczne "na sucho” sa zdominowane przez chrzaszcze (Coleoptera), wśród których przeważaja ryjkowce (Curculionoidea), obejmujace niemal 60000 okazów należących do ok. 1000 gatunków. Najcenniejszymi sa tu 2 okazy holotypowe: Otiorhynchus smreczyński i Bagous aliciae oraz 1 paratyp Brachysomus strawinskii (Ryc. 4E, F), opisane przez prof. Zdzisława Cmolucha, wieloletniego kierownika Zakładu Zoologii (obecnie Katedra Zoologii i Ochrony Przyrody), jednego $z$ najlepszych taksonomów środkowoeuropejskich w zakresie ryjkowców. Głównie dzięki Profesorowi oraz jego ówczesnym współpracownikom, dr Alicji Mindzie-Lechowskiej i dr hab. Jackowi Łętowskiemu, Wydział stał się jednym $z$ ważniejszych ośrodków w Polsce $\mathrm{w}$ zakresie badan ryjkowców. Obecnie badania te kontynuuje dr hab. Rafał Gosik, prof. UMCS, który nadal systematycznie powiększa zbiór tych chrzaszczy. Istotny udział $\mathrm{w}$ rozbudowie kolekcji Curculionoidea miał też prof. Bernard Staniec (obecny kierownik Katedry). Jest on również głównym autorem dużej kolekcji chrzaszczy kusakowatych (Staphylinidae), obejmujacej blisko 5000 okazów (ok. 850 gatunków), gromadzonych $\mathrm{z}$ przerwami od 
połowy lat 80. ubiegłego stulecia do chwili obecnej. Wśród nich najliczniej w kolekcji sa reprezentowane rodzaje Philonthus i Stenus. Z kolei zbiór gatunków rodzaju Bledius wydaje się być najbardziej kompletny w skali Polski. Obejmuje on bowiem niemal wszystkie krajowe gatunki, wśród których jest kilka taksonów unikatowych w skali kraju i Europy Centralnej, np.: Bledius agricultor O. Heer, 1841, B. baudii A. Fauvel, 1872, B. defensus A. Fauvel, 1872, czy B. terebrans (Schiødte, 1866), a jego dużą wartość dodatkowo podnosza liczne serie okazów, reprezentujacych poszczególne gatunki. Na szczególna uwagę zasługuje bardzo interesująca i „niszowa” grupa ekologiczna myrmekofilnych Staphylinidae, reprezentowana w zbiorze przez blisko 100 gatunków (kilkaset okazów), odłowionych w gniazdach kilku gatunków mrówek w południowo-wschodniej Polsce. Wśród nich jest 1 okaz holotypowy i 4 okazy paratypowe Thiasophila szujeckii Zagaja \& Staniec, 2015, gatunku opisanego jako nowy dla nauki, który zasiedla gniazda mrówki Formica truncorum (Fabricius, 1804) w okolicach Leżajska (Ryc. 4G, H).

Dość obszerny zbiór (ponad 200 gatunków i ok. 1100 okazów) stanowią także stonkowate (Chrysomelidae), pochodzące głównie $z$ różnych siedlisk Wyżyny Lubelskiej. Zostały zgromadzone i oznaczone przez dr hab. Ewę Pietrykowska-Tudruj, prof. UMCS oraz prof. B. Stańca. Pozostałe zbiory Coleoptera tworzą: kózkowate (Cerambycidae) - około 120 gatunków (650 okazów, Wyżyna Lubelska, Polesie Lubelskie, Podlasie, Tatry, wyspy Asinara i Galicja Wschodnia), zebranych i oznaczonych przez: dr. R. Rozwałkę, prof. J. M. Gutowskiego, mgr. W. Piotrowskiego, prof. B. Stańca, dr. hab. R. Gosika, J. Smutek, M. Sulmę i M. Rybińskiego); omomiłki (Cantharoidea) - 70 gatunków (400 okazów, Wyżyna Lubelska i Roztocze) złowionych i oznaczonych przez dr. Jacka Chobotowa; biegaczowate (Carabidae) - ok. 50 gat., (250 okazów, Wyżyna Lubelska, Polesie Lubelskie, Tatry), zebranych i oznaczonych przez prof. B. Stańca oraz dr. hab. R. Gosika; biedronkowate (Coccinellidae) - ok. 30 gat. (80 okazów, Wyżyna Lubelska, Roztocze, Polesie Lubelskie) złowionych i oznaczonych przez dr hab. E. Pietrykowska-Tudruj, prof. UMCS oraz mgr Z. Stączek.

\section{PLUSKWIAKI (HEMIPTERA)}

Stanowią w kolekcji drugi pod względem liczebności rząd owadów (ok. 50000 okazów, ponad 700 gatunków). Zbiór ten obejmuje zarówno gatunki wodne, lądowe, jak i o charakterze pośrednim, które pochodza $z$ obszaru całego obecnego terytorium Polski, liczbowo przeważają okazy $Z$ południowo-wschodniej części kraju (Wyżyna Lubelska, Polesie Lubelskie, Roztocze, Nizina Sandomierska, Beskid Niski oraz Bieszczady). Mniej obfite kolekcje pochodzą $z$ innych części Polski (Białowieski PN, Świętokrzyski PN, Chęcińsko-Kielecki PK, Bory Tucholskie). Ponadto, w zbiorach znajduje się ponad 5000 okazów zebranych w Bułgarii i Rumunii. Inne, nieliczne okazy zostały złowione w kilku krajach Europy. Wśród nich są 4 okazy paratypów Carpocoris mediterraneus Tamanini, 1958, pochodzace $z$ Calabrii we Włoszech (det. L. Tamanini, Ryc. 4I). Bogaty zbiór pluskwiaków jest efektem wieloletniej pracy (od 1945 r. do chwili obecnej) kilku osób, wśród których największy udział miał prof. Konstanty Strawiński, współorganizator UMCS, pierwszy dziekan Wydziału Matematyczno-Przyrodniczego, a następnie prorektor i dyrektor Instytutu Zoologicznego, twórca powojennej lubelskiej szkoły entomologii oraz pionier badań w zakresie biocenologii Heteroptera. Duży wkład w rozwój zbiorów Hemiptera, mieli również: dr Alicja Cmoluchowa, dr hab. Lech Lechowski, dr Zofia Smardzewska i dr Emilia Walczyk.

\section{MUCHÓWKI (DIPTERA)}

Obejmuja ponad 15000 okazów (ponad 600 gatunków), reprezentujących: bzygowate (Syrphidae), pryszczarkowate (Cecidomyiidae) i niezmiarkowate (Chloropidae). Znaczna cześć okazów Diptera czeka na uporzadkowanie. Kolekcja była kompletowana od końca lat 50. do połowy lat 80 . ubiegłego stulecia, głównie przez doc. dr hab. Józefę Daszkiewicz-Hubicka, uznana specjalistkę w zakresie systematyki, faunistyki i biomorfologii muchówek i wieloletnia pracownice Zakładu Zoologii Instytutu Biologii UMCS (lata 1950-1986). Jej zainteresowania były skoncentrowane na rodzinie Chloropidae, co zaowocowało m.in. opisem 6 nowych gatunków dla nauki: $M e^{-}$ romyza lolii, $M$. rostrata, $M$. rotundata, $M$. coronoseta, $M$. deuardi oraz Dicraneus polonicus; okazy typowe znajduja się w omawianych zbiorach.

Pozostałe owady przechowywane „na sucho" w zbiorach reprezentuja inne rzędy: ważki (Odonata) - ok. 11000 okazów (70 gatunków, imagines i wylinki larw), zebranych i oznaczonych przez dr. hab. Pawła Buczyńskiego, prof. UMCS; prostoskrzydłe (Orthoptera) - ok. 600 okazów (45 gatunków), złowionych, oznaczonych przez Zbigniewa Ślusarczyka i Jerzego Przywrzeja oraz wielbłądki (Raphidioptera) - ponad 100 okazów (7 gatunków), zebranych i oznaczonych przez mgr. Wojciecha Czerniawskiego. 

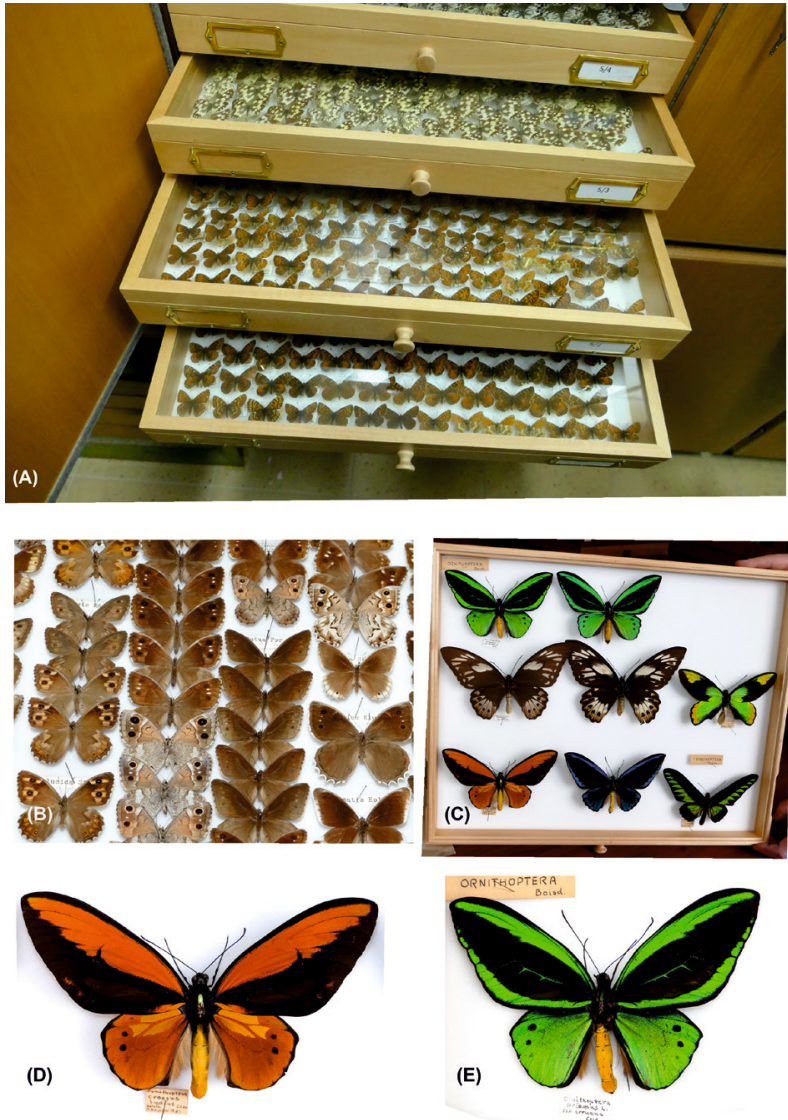

Ryc. 5. Okazy motyli $z$ kolekcji doc. mgr. inż. Mieczysława Romualda Krzywickiego: A, B - okazy w gablotach; C - wybrane okazy motyli egzotycznych; D - Ornithoptera craesusus lydius; E O. priamus ssp. arruana (fot. B. Staniec).

\section{MOTYLE DZIENNE (RHOPALOCERA)}

W 1989 r. Instytut Biologii UMCS w Lublinie zakupił kolekcję od spadkobierców doc. mgr. inż. Mieczysława Romualda Krzywickiego, lepidopterologa-samouka, zajmującego się faunistyka, ekologia i biologia motyli większych (Macrolepidoptera). Jest to jeden $z$ najbardziej kompletnych zbiorów motyli dziennych w Polsce, liczacy około 40000 okazów (Ryc. 5A, B). Oprócz ośrodka lubelskiego, motyle zgromadzone przez Krzywickiego zasiliły także zbiory entomologiczne Instytutu Systematyki i Ewolucji Zwierząt PAN w Krakowie oraz liczne kolekcje prywatne. Zdeponowane w Muzeum Zoologicznym Wydziału Biologii i Biotechnologii UMCS zbiory tego autora pochodza $z$ wielu krain geograficznych Polski, m.in. z Pojezierza Mazurskiego, Białowieży, Lubelszczyzny, Pienin, Tatr oraz $z$ wyjazdów zagranicznych do Bułgarii, Rumunii, USA i Kanady. Znajdują się w nich też liczne okazy reprezentujące gatunki z Azji, Afryki Północnej, innych rejonów Europy i Ameryki Północnej, wśród


Ryc. 6. Zbiory entomologiczne przechowywane „na mokro”: A, B - pudełka zbiorcze $z$ okazami przylżeńców $\mathrm{w}$ postaci preparatów mikroskopowych trwałych; C - przykład preparatu mikroskopowego $z$ okazem przylżeńca (widok od góry i od dołu) (fot. B. Staniec); D - spreparowany okaz Haplothrips carpathicus $\mathrm{w}$ powiększeniu mikroskopowym (fot. H. Kucharczyk); E - przechowywane "na mokro" okazy w regałach przesuwnych (fot. B. Staniec); F, G - przechowywane „na mokro" okazy w pojemnikach różnej wielkości (fot. P. Buczyński); $\mathrm{H}$ - okazy przechowywane „na mokro” w uszczelnionych probówkach typu eppendorf; I - materiał badawczy w alkoholu przed identyfikacja (fot. B. Staniec).

nich szereg efektownych form egzotycznych (Ryc. 5C-E), które pochodza $z$ wymiany okazów motyli $z$ kolekcjonerami zagranicznymi. Owady te zostały zebrane w okresie od końca XIX w. do połowy XX w. Szczególna uwage wśród tej kolekcji zwracaja 103 okazy paratypów oraz obecność wielu podgatunków, aberracji, a nawet form temperaturowych, wyróżnionych przez jej autora.

\section{ZBIORY ZABEZPIECZONE NA TRWAŁYCH PREPARATACH}

W omawianej kolekcji jedyną grupa owadów, których okazy zabezpieczono na trwa- 
łych preparatach, są przylżeńce (Thysanoptera) (Ryc. 6A-D). Zbiór ten obejmuje blisko 25000 okazów osobników dorosłych i larw, wśród których wyróżniono 220 gatunków (na 224 stwierdzone w Polsce). Jest to obecnie największy i najbardziej kompletny zbiór krajowych Thysanoptera. Na szczególna uwage zasługuje kilka okazów typowych, w tym 2 holotypy: Xylaplothrips zawirskae Kucharczyk 2008 i Taeniothrips zurstrasseni Zawirska 2007 oraz 1 paratyp Thrips latiareus Vierbergen 2004. Tak obszerna i wartościowa kolekcja jest efektem szczególnie żmudnej, ze względu na specyficzna preparatykę, wieloletniej pracy dr hab. Ireny Zawirskiej (lata 1959-2001) oraz dr hab. Haliny Kucharczyk, prof. UMCS (lata 1986-2020), specjalistek w zakresie faunistyki, taksonomii, morfologii i biologii Thysanoptera, uznanych w środowisku krajowym i międzynarodowym. Okazy przylżeńców pochodza $z$ różnych regionów Polski, z Lubelszczyzny, Mazowsza, Słowińskiego PN, Białowieskiego PN, Wielkopolski, Suwalszczyzny, Bieszczad, Sudetów i Tatr oraz $z$ innych państw europejskich, w tym liczne $z$ Bułgarii, Norwegii (obszerny zbiór gatunków Tubulifera i ich nimf $z$ kolekcji Sverre Kobro, ok. 200 preparatów), Węgier oraz Rosji, nieliczne $z$ Niemiec, Słowacji, Francji, a pojedyncze $z$ Macedonii, Słowenii, Portugalii i Turcji. Obecnie kolekcja przylżeńców jest już niemal w całości zdigitalizowana, uporzadkowana i posegregowana w oparciu o aktualna systematykę i nomenklaturę.

\section{ZBIORY PRZECHOWYWANE W ALKOHOLU, CZYLI „NA MOKRO”}

Zbiory przechowywane w alkoholu (Ryc. $6 \mathrm{E}-\mathrm{H})$, sa to głównie zbiory muchówek $\mathrm{Z}$ rodzaju Culicoides (Ceratopogonidae), zgromadzone przez: dr hab. Marię Grochowska, prof. UMCS i dr hab. Lecha Lechowskiego, prof. UMCS (ponad 2000000 okazów). Owady te były gromadzone $\mathrm{w}$ ramach monitoringu chorób przeżuwaczy wywoływanych przez wirusy przenoszone przez szereg gatunków $z$ tego rodzaju Diptera (wirus niebieskiego języka i wirus Schmallenberg). Większość kolekcji była kompletowana w latach 20132015 w ponad 40 miejscowościach różnych rejonów kraju, w tym w pobliżu stad żubrów w Białowieskim PN w 2014 r. W kolekcji tej zidentyfikowano 24 gatunki.

Efektem trzech tematów badawczych, finansowanych przez fundusz leśny Lasów Państwowych (2 projekty, lata 2016-2020) i Wojewódzki Fundusz Ochrony Środowiska i Gospodarki Wodnej w Lublinie (1 projekt), jest bogaty zbiór myrmekofilnych i saproksylicznych chrzaszczy (Coleoptera) oraz ich stadiów larwalnych, który pochodzi z Poleskiego PN (obie grupy ekologiczne) i z parków podworskich Lubelszczyzny (tylko gatunki saproksyliczne). Wszystkie okazy (13000 dorosłych i 2000 larw należących do 111 gatunków, odłowionych w gniazdach 6 gatunków mrówek) opracowano dotychczas w $70-80 \%$. Jest to prawdopodobnie jedyny tak kompletny i obszerny zbiór chrzaszczy myrmekofilnych w Polsce. W przypadku chrzaszczy saproksylicznych (15 000 okazów, 400 gatunków) wyróżniono szereg gatunków bardzo rzadkich (2-4 znane stanowiska) w kraju lub sa one wymieniane, jako tzw. relikty lasów pierwotnych. Chrzaszzcze myrmekofilne i saproksyliczne w Poleskim PN zostały zebrane przez prof. Bernarda Stańca, dr. Grzegorza Karola Wagnera, dr hab. Ewę Pietrykowska-Tudruj, prof. UMCS oraz dr. Mirosława Zagaję.

Kolejna interesujaca grupa ekologiczna jest zbiór chrząszczy zasiedlających owocniki hub nadrzewnych $(12000$ okazów, ok. 150 gatunków, w tym larwy i dorosłe), które pochodza ze wschodniej Polski, z Roztocza, Wyżyny Lubelskiej i Polesia Lubelskiego (lata 2013-2017) oraz z Ojcowskiego PN (20192020). Autorem tej kolekcji jest dr Grzegorz Wagner.

Bardzo cenny, choć jeszcze nieopracowany w całości, jest także zbiór przylżeńców (Thysanoptera), pochodzący $z$ różnych regionów Polski oraz $z$ Malezji (Borneo) i Armenii, autorstwa dr hab. Haliny Kucharczyk, prof. UMCS.

Istotna część zbiorów przechowywanych w alkoholu stanowia owady wodne, zebrane w latach 2006-2021. Sa to głównie ważki (Odonata), zbiór to 620000 okazów larw, 6000 wylinek i 6000 imagines, reprezentujących 80 gatunków oraz chrzaszcze wodne (Coleoptera Aquatica) - 3600 larw, 23 poczwarki, 42500 imagines, wśród których wyróżniono dotychczas blisko 200 gatunków. Dużą wartością tego zbioru jest to, że okazy pochodza nie tylko $z$ Polski, ale także $z$ wielu innych krajów europejskich, z Białorusi, Ukrainy, Słowacji, Czech, Niemiec, Wielkiej Brytanii, Portugalii, Włoch, Czarnogóry, Albanii, Macedonii, Bułgarii i Grecji, a także $z$ Wysp Kanaryjskich. Bardzo cenne sa też materiały $z$ Bałkanów, w tym $z$ wielu niezbadanych wcześniej regionów. Kolekcja zawiera m.in. okazy dowodowe Gomphus pulchellus, gatunku dysjunktywnego. Ten bogaty zbiór owadów wodnych jest efektem pracy dr hab. Pawła Buczyńskiego, prof. UMCS.

\section{PODZIE KOWANIA}

Składamy serdeczne podziękowania Anonimowemu Recenzentowi za wszystkie cenne uwagi, które znaczaco pomogły nam w przygotowaniu tej pracy. 


\section{Streszczenie}

Praca prezentuje historię powstania oraz zasoby cennych naukowych kolekcji botaniczno-mykologicznych i entomologicznych zgromadzonych na Wydziale Biologii i Biotechnologii Uniwersytetu Marii Curie-Skłodowskiej w Lublinie. Najstarsze $z$ nich pochodza $z$ połowy XIX wieku. Dodatkowo przedstawiono wkład niektórych autorów w tworzenie zbiorów i ich powiększanie, a także możliwości wykorzystania tych kolekcji w nauce.

\section{LITERATURA}

KÖHLER P., 2007. Zarys historii zielnika roślin naczyniowych Lubelszczyzny Zakładu Systematyki Roślin Instytutu Biologii UMCS w Lublinie. Kwart. Historii Nauki i Techniki 52, 191-216.

MiREK Z. 1997. Polish Herbaria - Polish Botanical Studies. Inst. Bot. Pol. Acad. Sci., Kraków.

KOSMOS Vol. 70, 2, 305-314, 2021

\section{Wiestaw MuŁenko ${ }^{1}$, Bernard StanieC ${ }^{2}$, Joanna CZarnecka ${ }^{1}$}

${ }^{1}$ Department of Botany, Mycology and Ecology, Institute of Biological Science, Maria Curie Sklodowska University, 19 Akademicka Str., 20-033 Lublin, ${ }^{2}$ Department of Zoology and Nature Protection, Institute of Biological Science, Maria Curie Sklodowska University, 19 Akademicka Str., 20-033 Lublin,E-mail: wieslaw.mulenko@mail.umcs.pl, bernard.staniec@mail.umcs.pl,

joanna.czarnecka@mail.umcs.pl

\section{SCIENTIFIC COLLECTION OF THE FACULTY OF BIOLOGY AND BIOTECHNOLOGY, MARIA CURIE-SKŁODOWSKA UNIVERSITY IN LUBLIN}

\section{Summary}

The work presents the history of the creation and the resources of valuable scientific botanical-mycological and entomological collections gathered at the Faculty of Biology and Biotechnology of the Maria Curie-Skłodowska University in Lublin. The oldest of them come from the mid-nineteenth century. Additionally, the contribution of some authors to the creation of collections and their enlargement as well as the possibilities of using these collections in science is presented.

Key words: biodiversity, botanical-mycological collections, entomological collections, Maria Curie-Skłodowska University, natural history collection 